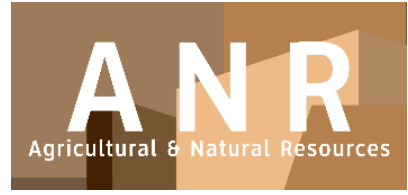

PAPER - OPEN ACCESS

\title{
Diversitas Genetik Populasi Tumbuhan Andaliman (Zanthoxylum acanthopodium DC.) Sumatera Utara Berbasis Molekuler
}

\author{
Author : Lollie Agustina P Putri \\ DOI $\quad: 10.32734 /$ anr.vli1.104 \\ Electronic ISSN : 2654-7023 \\ Print ISSN : :2654-7015
}

Volume 1 Issue 2-2018 TALENTA Conference Series: Agricultural \& Natural Resources (ANR)

This work is licensed under a Creative Commons Attribution-NoDerivatives 4.0 International License.

Published under licence by TALENTA Publisher, Universitas Sumatera Utara
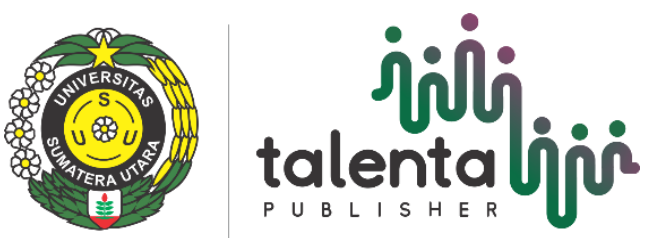


\title{
inili talentalioำ TALENTA Conference Series \\ P U B L I S H E R Available online at https://talentaconfseries.usu.ac.id \\ Diversitas Genetik Populasi Tumbuhan Andaliman (Zanthoxylum acanthopodium DC.) Sumatera Utara Berbasis Molekuler
}

\author{
Lollie Agustina P Putri ${ }^{a^{*}}$, Ayu O.Y. Sinaga ${ }^{a}$ Indri M S Sembiringa ${ }^{a}$ Hot Setiado ${ }^{a}$, Ann Sinaga ${ }^{a}$, \\ M K Bangun ${ }^{\mathrm{a}}$ \\ ${ }^{a}$ Fakultas Pertanian, Universitas Sumatera Utara, Medan 20155, Indonesia \\ lollie_agustina@yahoo.com
}

\begin{abstract}
Abstrak
Andaliman adalah tumbuhan yang khas dijumpai di Sumatera Utara dan hanya dikenal untuk masakan Batak serta tumbuh secara liar. Saat ini dikhawatirkan akan menjadi punah karena mengalami penurunan jumlah individu (tidak ada upaya membudidayakan). Diversitas genetik suatu tumbuhan sangat penting karena akan mempengaruhi eksistensinya di alam dan diperlukan untuk program pemuliaan tanaman. Tujuan penelitian ini untuk mengklarifikasi keragaman genetik populasi andaliman Sumatera Utara. Sebanyak 30 aksesi andaliman dari berbagai ketinggian yang digunakan berasal dari 3 populasi yaitu dari Kabupaten Dairi, Tanah Karo dan Simalungun. Analisis molekuler RAPD dilakukan dengan menggunakan 10 primer acak. Kesepuluh primer tersebut menghasilkan 50 pola pita DNA, dengan tingkat polimorfisme mencapai $90 \%$. Selanjutnya koefisien keragaman genetik dan dendogram filogenetik diperoleh menggunakan software Darwin 6.0 dan GenAlEx 6.502. Hasil ini menunjukkan bahwa 30 aksesi andaliman tersebut dikelompokkan menjadi tiga kelompok. Dalam setiap kelompok terdapat aksesi andaliman yang berasal dari tiga kabupaten tersebut dan dari ketinggian yang berbeda, artinya setiap aksesi andaliman tidak mengelompok berdasarkan daerah dan ketinggian tempatnya. Hasil penelitian ini menunjukkan bahwa 30 aksesi dari tiga lokasi menunjukkan keragaman genetik yang tinggi.
\end{abstract}

Kata Kunci: andaliman; keragaman genetik; RAPD (random amplified polymorphism DNA);

\section{Pendahuluan}

Andaliman (Zanthoxylum acanthopodium DC.), famili Rutaceae, adalah tanaman yang khas dijumpai di Sumatera Utara, Indonesia dan hanya dikenal untuk masakan Batak serta tumbuh secara liar. Saat ini dikhawatirkan akan menjadi punah karena mengalami penurunan jumlah individu (tidak ada upaya membudidayakan). Bentuknya mirip lada (merica) bulat kecil berwarna hijau, tetapi jika sudah kering, agak kehitaman. Bila digigit tercium aroma minyak atsiri yang wangi dengan rasa khas getir. Diversitas genetik suatu tumbuhan sangat penting karena akan mempengaruhi eksistensinya di alam [1] dan diperlukan untuk program pemuliaan tanaman.

Andaliman memiliki kandungan minyak atsiri yang tinggi yang dapat dimanfaatkan sebagai antioksidasi dan antimikroba alami. Namun, belum terdapat budidaya andaliman yang cukup luas yang dijumpai di Indonesia. Hal ini selain disebabkan oleh tanamannya yang tumbuh liar, menurut Siregar [7] andaliman juga memiliki daya perkecambahan yang sangat rendah dan daya adaptasi yang rendah.

Karakteristik ini dapat menjadi penting untuk studi populasi dan untuk menginformasikan keputusan tentang konservasi populasi (Williams et al., 1991). Salah satu penanda molekuler untuk analisis keragaman genetik adalah 
Randomly Amplified Polymorphic DNA (RAPD) dan merupakan teknik yang sangat berguna untuk identifikasi genotipik, analisa kekerabatan, filogenetik dan pemetaan genetik (Yu dan Nguyen, 1994).

Pemuliaan andaliman belum pernah dilakukan sehingga masih minim sekali informasi genetiknya terutama informasi keragaman genetik andaliman yang berbasis molekuler. Untuk memperbaiki atau mengembangkan sifat sifat tertentu perlu diketahui bagaimana tingkat variabilitas genetiknya. Untuk mengembangkan tanaman andaliman ini, diperlukan informasi-informasi penting tentang tanaman tersebut, seperti keanekaragaman genetik tanaman andaliman yang dapat dimanfaatkan sebagai langkah awal dalam pemuliaan tanaman.

Pemakaian marka molekuler untuk andaliman Indonesia belum banyak digunakan, sehingga informasi mengenai molekuler andaliman masih minim. Penilaian keragaman genetik tanaman dapat dilakukan dengan menggunakan penanda molekuler DNA salah satunya dengan marka RAPD (Random Amplified Polymorphic DNA). Penelitian ini bertujuan untuk mengetahui keragaman genetik andaliman Sumatera Utara berdasarkan 10 marka RAPD.

\section{Bahan Dan Metode}

\subsection{Isolasi, Penetapan Kemurnian dan Konsentrasi DNA Genom Asal Daun}

Semua kegiatan penelitian dilakukan di Laboratorium Terpadu Fakultas Kedokteran dan Laboratorium Kultur Jaringan Fakultas Pertanian Universitas Sumatera Utara. Bahan tanaman yang digunakan adalah daun muda andaliman dari populasi alam dari daerah Kabupaten Dairi (18 aksesi), Kabupaten Tanah Karo (3 aksesi) dan dari Kabupaten Simalungun (9 aksesi) dengan total sebanyak 30 aksesi (Sinaga, 2015)

Ekstraksi DNA dari daun andaliman dilakukan sesuai dengan prosedur standard Orozco-Castillo et al., (1994) dilakukan menurut metode CTAB yang dimodifikasi khususnya penambahan antioksidan polyvinilpolypirolidon (PVPP) (Toruan-Matius et al., 1996) dan merkaptoetanol selama melakukan penggerusan contoh dan ke dalam buffer ekstrak dan nitrogen cair. Pemurnian DNA genom dilakukan dengan menggunakan campuran kloroform : isoamilalkohol (24:1), disentrifusi dengan mesin Eppendorf 5415D pada kecepatan 11.000 rpm selama 5 menit. Pemurnian dilakukan dua kali sampai terbentuk emulsi. Cairan bagian atas ditambahkan dengan $1 \mathrm{ml}$ isopropanol dingin dan dikocok perlahan-lahan sampai terbentuk benang-benang halus berwarna putih. Pelet DNA yang diperoleh dari hasil sentrifusi dikering-anginkan dengan membalikkan tabung selama 5 menit, pada suhu kamar. Pelet yang dihasilkan dicuci dengan $5 \mathrm{ml}$ alkohol dingin 70\%, disentrifusi dan peletnya dilarutkan dalam $5 \mathrm{ml}$ Tris EDTA (TE). Pencucian dilakukan beberapa kali, selanjutnya DNA dilarutkan dalam $1 \mathrm{ml}$ larutan TE di tabung Ependorf dan disimpan pada suhu $-20^{\circ} \mathrm{C}$.

DNA dari hasil amplifikasi dipisahkan dengan menggunakan elektroforesis $1.4 \%$ agarose yang diberi pewarnaan ethidium bromida, selama 80 menit dengan voltase $50 \mathrm{~V}$. Hasil elektroforesis divisualisasikan dan didokumentasikan dengan Gel Doc UVITEC.

\subsection{Analisis Data}

Analisis dilakukan secara deskriptif, berdasarkan ada tidaknya fragmen DNA yang dihasilkan. Pola fragmen RAPD diubah menjadi data biner. Data hasil RAPD diskor berdasarkan ada atau tidaknya pita. Sampel yang memiliki pita (band) diberi skor 1 sedangkan yang tidak mempunyai pita diberi skor 0. Setelah itu dilakukan analisis variasi genetik dan jarak genetik menggunakan software DARwin6 (Perrier dan Jacquemoud-Collet 2015) dan GenAlEx 6 [4]. Matriks jarak atau ketidaksamaan genetik untuk semua kombinasi pasangan individu dapat dilakukan dengan dua tipe analisis deskriptif dari keragaman: Principal Coordinates Analysis (PCoA), suatu jenis analisis faktorial pada tabel ketidaksamaan untuk mendapatkan group origin utama dan Neighbour-Joining Tree (NJtree) berdasarkan Saitou dan Nei (1978) untuk memperoleh gambaran dari kekerabatan diantara individu-individu. Perhitungan dan analisis deskriptif ini menggunakan software DARwin6 [5]. Selain itu, untuk mengetahui pengaruh kabupaten (wilayah), antar individu dalam kabupaten dan di dalam populasi yang berkontribusi terhadap perbedaan keragaman genetik menggunakan Analisis Molekuler Varians (AMOVA). 


\section{Hasil Dan Pembahasan}

\subsection{Polimorfisme Penanda RAPD}

Sepuluh primer yang digunakan dalam penelitian ini menghasilkan 50 pita dengan kisaran ukuran dari $300 \mathrm{bp}-$ $6000 \mathrm{bp}$. Dari lima puluh pita yang dihasilkan, 45 pita bersifat polimorfik dan 5 monomorfik yang menunjukkan pola pita yang sama pada semua individu yang dicobakan. Primer OPC-07 menghasilkan jumlah pita yang paling banyak (8 pita) diikuti oleh OPD-20 (7 pita), OPN-10 dan OPM-01 (6 pita), OPI-20 (5 pita), OPD-13, OPN-09 dan OPM-20 (4 pita) dan yang paling sedikit adalah OPD-03 dan OPH-09 (3 pita). Tingkat polimorfisme kesepuluh primer tersebut mencapai $90 \%$ (Tabel 1).

Tabel 1.Total pita, pita monomorfik dan polimorfik yang dihasilkan dari amplifikasi DNA pada 26 individu dengan menggunakan 6 primer RAPD

\begin{tabular}{lllll}
\hline Primer & Urutan Basa $\left(5^{\circ} \rightarrow 3^{\circ}\right)$ & Total Pita & Pita monomorfik & Pita polimorfik \\
\hline OPD-13 & GGGGTGACGA & 4 & 0 & 4 \\
OPI-20 & AAAGTGCGGG & 5 & 0 & 5 \\
OPM-01 & GTTGGTGGCT & 6 & 2 & 4 \\
OPN-09 & TGCCGGCTTG & 4 & 0 & 4 \\
OPD-03 & GTCGCCGTCA & 3 & 1 & 2 \\
OPD-20 & ACCCGGTCAC & 7 & 0 & 7 \\
OPC-07 & GTCCCGACGA & 8 & 0 & 8 \\
OPM-20 & AGGTCTTGGG & 4 & 0 & 4 \\
OPH-09 & TGTAGCTGGG & 3 & 1 & 2 \\
OPN-10 & ACAACTGGGG & 6 & 1 & 5 \\
\hline
\end{tabular}

Hasil analisis terhadap profil pita masing-masing individu dari 3 populasi, terlihat ada kecenderungan pola pita yang berbeda antar 3 populasi yang dikaji dan dijumpai pita-pita unik yang terdapat pada suatu populasi dan tidak ditemui pada populasi lain. Pada populasi Dairi dijumpai total 42 pita dengan 7 pita unik (private), populasi Tanah Karo dijumpai total 35 pita dengan 2 pita unik (private) dan populasi Simalungun dijumpai total 41 pita dengan 3 pita unik (private). Tingginya polimorfisme pita pada penelitian ini menunjukkan tingginya keragaman genetik pada tumbuhan andaliman yang diamati. Secara umum, menurut Lynch dan Milligan (1994) RAPD dapat memberikan data berharga tentang variasi genetik di dalam dan antara populasi.

Hasil analisis GenAlEx untuk diversitas genetik Z. acathopodium pada masing-masing populasi (Dairi, Tanah Karo dan Simalungun) menunjukkan bahwa diversitas genetik di dalam populasi Dairi, Tanah Karo dan Simalungun cukup tinggi. Nilai diversitas genetik tertinggi diperoleh pada populasi Dairi dengan nilai rata-rata heterozigositas $(H)$ sebesar 0.176 dan rata-rata nilai Indeks Shannon $(I)$ sebesar 0.272, kemudian dalam populasi Simalungun dengan nilai $H$ sebesar 0.172 dan nilai $I$ sebesar 0.260 . Populasi Tanah Karo memiliki nilai $H$ terendah yaitu sebesar 0.133 dan $I$ sebesar 0.191 (Tabel 2).

Tabel 2. Diversitas genetik Z. acathopodium pada populasi Dairi, Tanah Karo dan Simalungun

\begin{tabular}{lccccc}
\hline \multicolumn{1}{c}{ Populasi } & $\begin{array}{l}\text { Jumlah } \\
\text { Sample }\end{array}$ & $N a$ & Ne & H & I \\
\hline Dairi & 18 & 1.5 & $1.292 \pm 0.051$ & $0.176 \pm 0.026$ & $0.272 \pm 0.038$ \\
Tanah Karo & 3 & 1 & $1.240 \pm 0.052$ & $0.133 \pm 0.029$ & $0.191 \pm 0.042$ \\
Simalungun & 9 & 1.4 & $1.287 \pm 0.050$ & $0.172 \pm 0.027$ & $0.260 \pm 0.040$ \\
\hline
\end{tabular}

Keterangan: Na : Rata-rata jumlah alel yang diamati;Na: rata-rata jumlah alel; Ne: Rata-rata jumlah alel efektif; $H$ : Rata-rata Heterozigositas; I: Rata-rata Indeks Shannon (Lewontin, 1972) 
Perbedaan nilai heterozigositas di dalam populasi Dairi, Tanah Karo dan Simalungun diasumsikan antara lain terkait dengan ukuran populasinya (jumlah individu). Pengurangan ukuran populasi merupakan hal yang utama yang menyebabkan hilangnya diversitas genetik, khususnya disebabkan karena ukuran populasi efektif biasanya lebih kecil dibandingkan jumlah individu reproduktif dalam populasi tersebut [2].

\subsection{Struktur Genetik dan Pengelompokan Berdasarkan Profil RAPD}

Hasil analisis AMOVA mennjukkan bahwa sebagian besar ragam genetik (78\%) disebabkan oleh perbedaan antar individu dalam satu populasi (within populations) daripada antar populasi dari daerah berbeda (among populations) yang hanya $22 \%$. $(P=0,001 ;$ Tabel 3.$)$

Tabel 3. Pembagian ragam genetik secara hirarki di antara dan di dalam populasi Z. acathopodium berdasarkan analysis of molecular variance (AMOVA).

\begin{tabular}{lccccc}
\hline \multicolumn{1}{c}{ Sumber ragam } & $\mathrm{dB}$ & $\begin{array}{c}\text { Jumlah } \\
\text { kuadrat }\end{array}$ & $\begin{array}{c}\text { Kuadrat } \\
\text { tengah }\end{array}$ & $\begin{array}{c}\text { Estimasi } \\
\text { ragam }\end{array}$ & $\begin{array}{c}\text { Persentase } \\
\text { Ragam }\end{array}$ \\
\hline Antar populasi & 2 & 31.534 & 15.767 & 1.362 & $22 \%$ \\
Dalam populasi & 27 & 127.905 & 4.737 & 4.737 & $78 \%$ \\
Total & 29 & 159.439 & & 6.099 & $100 \%$ \\
\hline
\end{tabular}

Hasil analisis faktorial PCoA menunjukkan bahwa aksis 1 (23.39\%) dan aksis 2 (20.61\%), total keseluruhannya mampu menjelaskan keragaman molekuler sebesar $44 \%$ (Gambar 1). Tiga puluh aksesi tersebar pada kuadran yang berbeda. Hasil perhitungan analisis hubungan genetik untuk koefisien kesamaan genetik menunjukkan bahwa 30 aksesi andaliman terbagi dalam 3 group besar (Gambar 2).

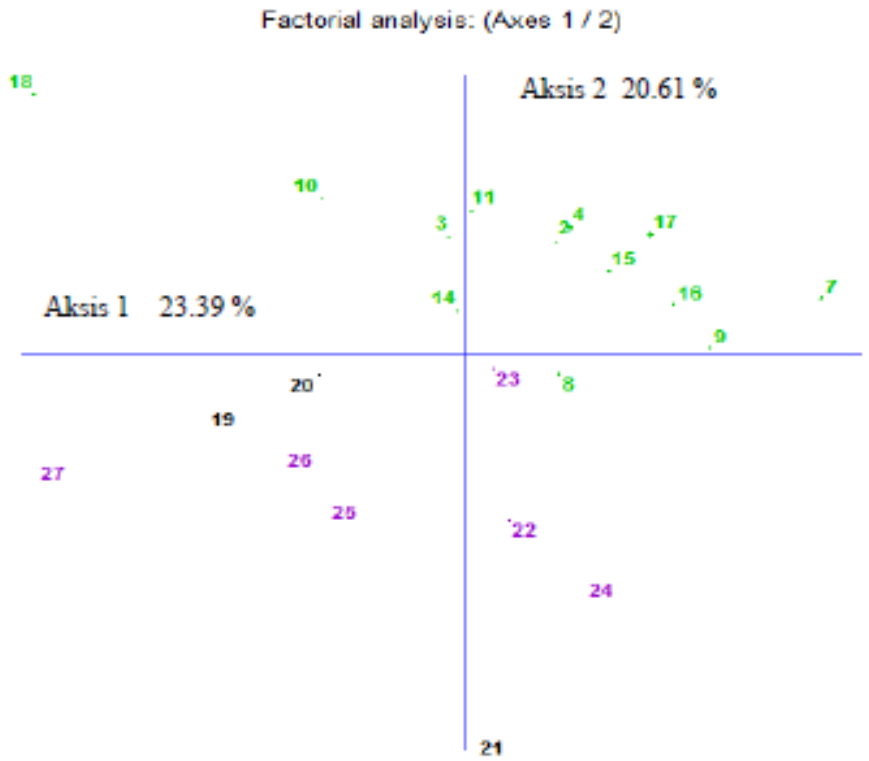

Gambar 1. Faktorial analisis (Principal Coordinate Analysis) aksis 1 (horizontal) dan aksis 2 (vertikal) dengan 10 primer marka RAPD. Keterangan : individu 1- 18= Dairi ; 19-21= Tanah Karo, dan 22-30= Simalungun 
Pengelompokan berdasarkan DARwin seperti yang tertuang pada Gambar 2 di bawah ini. Pada group I terdiri atas 14 aksesi yaitu aksesi 7, $8,9,15,16,19,20,21,22,23,24,25,26$, dan 27, pada group II terdiri atas 2 aksesi yaitu aksesi 2 dan 17, sedangkan pada group III terdiri atas 6 aksesi yaitu aksesi 3, 4, 10, 11, 14, dan 18. Aksesi yang berasal dari Kabupaten Dairi menyebar pada ketiga group, sedangkan aksesi yang berasal dari Kabupaten Karo dan Kabupaten Simalungun pada Group I saja.

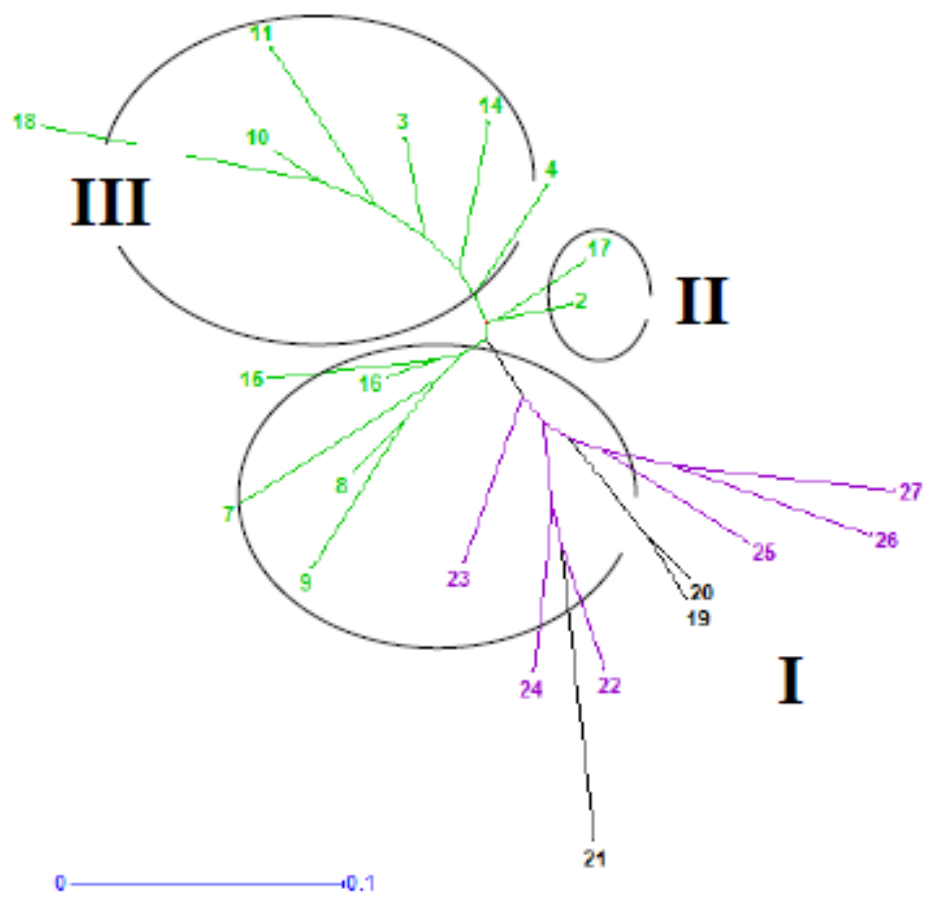

Gambar 2. Profil radial neighbor-joining 30 aksesi andaliman yang dianalisis berdasarkan Matrix Dissimilarity Simple Matching. Keterangan : individu 1- 18= Dairi ; 19-21= Tanah Karo, dan 22-30= Simalungun

Pada penelitian ini, persentase lokus yang polimorfik dapat menjadi acuan untuk melihat kekayaan diversitas gen. Aksesi andaliman yang masih memiliki keragaman yang tinggi diduga masih sedikit mengalami penekanan seleksi.

\section{Kesimpulan}

Sepuluh primer RAPD (primer OPC-07, OPD-20, OPN-10, OPM-01, OPI-20, OPD-13, OPN-09, OPM-20, OPD-03 dan OPH-09) memberikan 45 lokus polimorfik dan dapat digunakan untuk analisis keragaman genetik plasma nutfah andaliman.

Pendugaan analisis keragaman genetik dari 30 aksesi andaliman populasi alam membentuk pada 3 group utama. Populasi yang memiliki heterozigositas tertinggi adalah populasi Dairi. Heterozigositas antar populasi lebih kecil dari heterozigositas dalam populasi. Rata-rata nilai keragaman genetik yang cukup tinggi dari masing-masing populasi dan jarak genetik yang cukup besar antara populasi memberikan kesempatan yang cukup besar untuk melakukan pemuliaan terhadap jenis Z.acanthopodium. 


\section{Referensi}

[1] Godt, J.W. and Hamrick, J.L. 1996. Genetic structure of two endanger pitcher plants, Sarracenia jonesii and Sarracenia oreophila (Sarraceniaceae). Amer. J. Bot. 83: 1016-1023

[2] Frankham, R, J. D. Ballou \& D. A. Briscoe. 2002. Introduction to conservation genetics. Cambridge University Press. UK.

[3] Orozco-Castillo, K.J. Chalmers, R.Waugh \& W. Powell, 1994. Detection of genetic diversity and selective gene introgression in coffe using RAPD markers. Theor. Appl. Genet. 87. $934-940$.

[4] PEAKALL, R. and P.E. SMOUSE. 2006. GENALEX 6: genetic analysis in Excel. Population genetic software forteaching and research. Molecular Ecology Notes 6:288-295.

[5] Perrier X. dan Jacquemoud-Colled J.P., (2006). DARwin Software. http://darwin.cirad.fr/darwin

[6] Setiyo, I. E. 2001. Pemetaan dan keragaman genetik RAPD pada kelapa sawit Pancur (RISPA). Tesis. PPS IPB. Bogor. (Tidak dipublikasikan).

[7] Siregar, B. L., 2003. Andaliman (Zanthoxylum acanthopodicum DC.) di Sumatera Utara: Deskripsi dan perkecambahan. J. Hayati hlm. 3840

[8] Toruan-Matius, N., T. Hutabarat., T. Sundari. 1996. Pengaruh pengemasan dan penyimpanan terhadap DNA tanaman perkebunanuntuk analisis RAPD. Men. Perkub. 64 (1): 3-12. 